\title{
Transformasi Pesantren \\ (Studi terhadap Dialektika Kurikulum dan Kelembagaan Pondok Pesantren Rifaiyah Pati)
}

\author{
Amir Mahmud \\ Institut Teknologi Adhi Tama Surabaya \\ Email: amir.mifmuh@gmail.com \\ Zaini Tamin AR \\ Sekolah Tinggi Agama Islam YPBWI Surabaya \\ Email: zai_nino@yahoo.co.id
}

\begin{abstract}
Abstrak
Penelitian ini bermaksud menganalisis perubahan kurikulum pesantren yang kini menjadi diskursus disebabkan dinamika kebijakan pengembangan kurikulum pendidikan nasional. Pada saat yang sama, dinamika pesantren dalam mengembangkan kurikulum, dengan mendirikan lembaga pendidikan formal yang menyerap substansi kurikulum yang diperlukan oleh masyarakat. Penulis menjadikan pondok pesantren Rifaiyah Pati sebagai objek penelitian mengingat pesantren ini survive dengan pengembangan kurikulum yang dialektis. Dengan menggunakan pendekatan kualitatif, data yang dikumpulkan dianalisis dengan narasi induktif, kemudian disajikan secara kronologis-analitis. Temuan penelitian ini adalah bahwa perkembangan pesantren Rifaiyah mempunyai beberapa kasus yang unik dan dinamis, mulai pergeseran orientasi pengembangan kurikulum, tradisi intelektual, hingga pada pertentangan yang disebabkan oleh ketidaksepemahaman mengenai arah ideologis pesantren. Kasus-kasus spesifik ini tentu saja berpengaruh terhadap kebijakan kelembagaan yang dijalankan oleh pesantren Rifaiyah dalam mewujudkan visi, misi dan tujuanya ke depan. Dari hal ini, penulis menarik benang merah bahwa perubahan pondok pesantren kerap dimulai dari kurikulum, kemudian merambah ke aspek yang lain seperti kelembagaan.
\end{abstract}

Kata Kunci: Kurikulum, Pesantren, Lembaga Pendidikan Islam

\section{Pendahuluan}

Sebagai lembaga pendidikan yang khas di Indonesia, pesantren merupakan salah satu jenis pendidikan yang bersifat tradisional untuk mendalami ilmu agama Islam, dengan pendidikan moral dalam hidup di tengah masyarakat. Saat ini eksistensi pesantren diakui sebagai lembaga 
pendidikan yang ikut mencerdaskan kehidupan bangsa, dengan banyaknya tokh penjuang kemerdekaan, dan tokoh bangsa ini (termasuk presiden ke 4 RI, yaitu; Abdurrahman Wahid), yang dilahirkan dari rahim pesantren, termasuk di antara banyak tokoh-tokoh bangsa sekarang yang berawal dari pendidikan pesantren. Penelitian terdahulu terkait pesantren senada bahwa pesantren berakar dari sistem pendidikan agama jawa menjadi lembaga pendidikan Islam Indonesia. Agama jawa (abad 8-9 M) merupakan perpaduan kepercayaan Hinduisme dan Budhisme. Di bawah pengaruh Islam, sistem pendidikan tersebut diambil alih dengan mengganti nilai ajaranya menjadi nilai ajaran Islam. ${ }^{1}$ Sejak akhir abad 15 Islam telah menggantikan Hiduisme, dan pada abad ke 16 dengan munculnya kerajaan Demak sebagai kerajaan Islam, penduduk jawa telah berhasil diislamkan. ${ }^{2}$

Perubahan dunia pendidikan di berbagai daerah di Indonesia, sedikit banyak memberikan tantangan terhadap keberadaan lembaga pendidikan tradisional seperti pesantren. Dalam beberapa kasus, tidak banyak pesantren yang mampu bertahan. Kebanyakan tergerus dengan sistem pendidikan umum atau setidaknya menyesuaikan diri dan mengadopsi isi dan metodologi pendidikan umum. ${ }^{3}$ Respon pesantren dalam menghadapi tantangan tersebut paling tidak dilakukan denga dua cara, yaitu; pertama, merubah kuikulumnya. Kedua, membuka kelembagaan dan fasilitas pendidikan umum. Di beberapa pesantren bahkan ada yang mendirikan lembaga pendidikan umum yang berada di bawah sistem kementerian pendidikan dan kebudayaan. ${ }^{4}$ Dengan kata lain, pesantren saat ini bukan hanya mendirikan madrasah, tetapi juga sekolah-sekolah umum. Bahkan banyak pesantren telah mendirikan SMK yang mengikuti sistem dan kurikulum kementerian pendidikan dan kebudayaan. ${ }^{5}$

${ }^{1}$ Mastuhu, Dinamika Sistem Pendidikan Pesantren (Jakarta: INIS, 1994), 3.

${ }^{2}$ Zamakhsari Dhofier, Tradisi Pesantren; Studi tentang Pandangan Hidup Kiai dan Visinya Mengenai Masa Depan Indonesia (Jakarta; LP3ES, 2011), 8.

3 Azyumardi Azra, Pendidikan Islam; Tradisi dan Modernisasi di Tengah Tantangan Millenium III (Jakarta: Kencana Prenada Media Grup dan UIN Jakarta Press), 117.

${ }^{4}$ Hal ini juga terjadi di pesantrren Rifaiyah selaku yang dijadikan objek penelitian. Pesantren Rifaiyah tidak hanya menyelenggarakan pendidikan Madrasah yang dibawah naungan Kementrian Agama yaitu MI dan MTs Miftahul Muhtadin, tetapi juga mengelola sekolah umum yang dibawah naungan oleh Departemen Pendidikan dan Kebudayaan. Yaitu dengan mendirikan SMA Rifaiyah. Lihat, Ramli Rasyid, "The Integration of the National Curriculum into Pesantren Education System”, JICSA, Vol. 1, No. 2 (December 2012).

${ }^{5}$ Azra, Pendidikan Islam, 127. 
Sistem pendidikan serta kurikulum pesantren selalu menjadi diskursus hangat tidak hanya karena dinamisnya kebijakan pengembangan kurikulum pendidikan nasional. Dinamika pesantren dalam mengembangkan kurikulum juga membentuk lembaga pendidikan formal yang menyerap muatan kurikulum yang dibutuhkan masyarakat yang mampu mengeluarkan ijazah, sebagai suatu formalitas kelulusan dalam menjalani program pendidikan. ${ }^{6}$ Pada saat yang sama, ada penambahan mata pelajaran umum di dalam sekolah keagamaan (dalam hal ini adalah pesantren dan lembaga pendidikan Islam) sebagai suatu wujud tantangan kebutuhan zaman akan kebutuhan pendidikan yang memberikan orientasi pengajaran, dan pemberian bekal hidup yang berbeda. Keadaan yang seperti ini juga belaku pada pengembangan pendidikan Islam (terutama dalam pengembangan kurikulum pendidikan) pondok pesantren Rifaiyah Pati. ${ }^{7}$ Pondok pesantren Rifaiyah awalnya hanya pesantren yang hanya mengajarkan kitab kuning dan kitab berbahasa arab pegon yang menjelaskan tentang pembelajaran Agama saja. Namun, dalam perkembangannya juga mengembangkan kurikulumnya dengan membentuk lembaga pendidikan yang mengakomodir kepentingan masyarakat. Dalam konteks ini, munculnya program pendidikan baru tersebut pesantren Rifaiyah tetap pada keinginan untuk mengakomodir kebutuhan masyarakat akan pendidikan formal. Di sisi lain, pesantren Rifaiyah juga tetap menyelenggarakan pendidikan sesuai dengan visi lembaga.

6 Lihat, Zaini Tamin AR, "Dinamika Perkembangan Kurikulum Pendidikan Pesantren; Satu Analisis Filosofis", El-Banat: Jurnal Pemikiran dan Pendidikan Islam, Vol. 8, No. 1 (Juni 2018).

${ }^{7}$ Pesantren Rifaiyah yang dimaksud adalah adalah pesantren Rifaiyah yang berada di kabupaten Pati letaknya di desa Sundoluhur kecamatan Kayen kabupaten Pati, di beberapa daerah di Jawa Tengah ada pesantren Rifaiyah yang didukung oleh masyarakat Tarjumah yaitu; di Temanggung, Kendal, Wonosobo, Batang, Pekalongan, Demak, kab Semarang, Kudus dan Grobogan. Sedangkan untuk di daerah Pati sendiri pesantren Rifaiyah ada di lima desa di tiga kecamatan yang berbeda, yaitu desa Tambah Agung, kecamatan Tambakromo, desa Baturejo dan, desa kedungwinong di kecamatan Sukolilo, dan di desa Talun kecamatan Kayen. Sampai sekarang pesantren Rifaiyah di daerah Pati yang masih eksis hanya di desa Sundoluhur dan desa Talun keacamatan kayen. Akan tetapi karena pesantren Rifaiyah Talun hanya menyelenggarakan pendidikan pesantren tanpa menyelenggarakan pendidikan formal. Oleh karena itu penulis mengambil objek penelitian pesantren rifaiyah di desa Sundoluhur yang tidak hanya menyelenggarakan pendidikan pesantren tetapi juga pendidikan formal, yaitu Sekolah dan Madrasah. 
Kurikulum pesantren Rifaiyah memberikan pengajaran kepada para santrinya dan masyarakat layaknya pesantren pada umumnya yaitu mengajari dasar-dasar pengetahuan agama yaitu, pembahasan seputar ushul, fiqih dan tasawuf. Pembahasan ini disajikan dalam bentuk yang menarik dan menggunakan kitab tarajumah karangan Syaikh Ahmad Rifai Kalisalak. Orang awam sering menyebutnya dengan kitab Arab Pegon, yaitu kitab yang ditulis dengan huruf Arab tetapi berbahasa jawamelayu. Seiring dengan perkembangan zaman, pesantren Rifaiyah harus mengakomodasi tuntutan kemajuan dan pendidikan, baik itu tuntutan persekolahan umum, atau megenai system pendidikan Nasional, dan SKB tiga menteri, pesantren Rifaiyah harus mengakomodir tuntutan masyarakat serta tidak menghilangkan keunikanya sebagai pesantren Tarajumah yang mempunyai keunikan tersendiri.

Problem adaptasi dengan kemajuan dan sistem pendidikan ini sedikit banyak akan mempengaruhi pengembangan kurikulum di pesantren Rifaiyah. Ditambah lagi dengan banyaknya Ustadz dan para Guru yang mempunyai pengalaman baru dan gelar kesarjanaan yang baru yang belum pernah di dapatkan oleh para ustadz di pesantren sebelumnya, ini memungkin membuka paradigm baru yang ada dalam pesantren Rifaiyah tersebut. Banyaknya alumnus al-Azhar Kairo Mesir membuat semangat purifikasi Islam menguat, ini merupakan masalah tersendiri terhadap adaptasi dan dinamika pengembangan pesantren Rifaiyah.

Bentuk asal kurikulum Pesantren Rifaiyah adalah pesantren tradisional yang mengajarkan Kitab-kitab klassik (kitab kuning), dan dengan penambahan muatan kitab tarajumah (kitab Arab Pegon) yang menjadi muatan inti dalam pengajaran agama di pesantren Rifaiyah, baik itu di ajarkan dalam bentuk hafalan bait, lafal makna, maupun membaca kitab secara keseluruhan. Dan pengembangan keilmuan membaca kitab kuning melalui nahwu dan sharaf, dengan metode pembelajaran sorogan dan bandongan. Kegiatan pembelajaran pesantren klasik tersebut mengalami perubahan dan dinamika seiring dengan perubahan dan dinamika pengembangan pesantren Rifaiyah seiring dengan meningkatnya tuntutan zaman, sistem pendidikan, dan alumni dan ustadz yang mempunyai paradigma modern yang ingin melakukan perubahan kurikulum dan pembelajaran di pesantren Rifaiyah Pati.

\section{Model Pengembangan Kurikulum Pesantren}

Lembaga pesantren adalah lembaga tradisional pendidikan untuk memahami, menghayati dan mengamalkan ajaran agama Islam dengan menekankan pentingnya moral sebagai pedoman hidup di tengah 
masyarakat. ${ }^{8}$ Di pesantren ada unsur kiai, pondok, masjid, santri, dan pengajaran kitab-kitab kuning yang saling bersinggungan dan berkaitan. Kiai berkewajiban mendidik, santri sebagai anak didik, masjid tempat penyelenggaraan pendidikan, shalat berjamaah dan sebagainya, serta pondok atau asrama sebagai tempat tinggal santri. ${ }^{9}$

Dewasa ini hampir di semua jenis pesantren terdapat tipologi pendidikan. Di antaranya yaitu; Pertama, pesantren yang hanya mempelajari agama dengan kitab-kitab keagamaan klassik atau "kitab kuning" dan berbentuk non-formal; Kedua, madrasah (sekolah agama); Ketiga, sekolah umum; Keempat, perguruan tinggi, baik agama atau umum. ${ }^{10}$ Ketiga jenis pendidikan terakhir ini berbentuk pendidikan formal, tetapi keempatnya hidup dalam satu kampus pesantren, dan oleh karena itu semua siswanya disebut santri.

Pesantren memiliki prinsip-prinsip yang didasarkan atas prinsip ajaran Islam yang mendasari lembaga tersebut. Seperti yang disebutkan sebelumnya bahwa pesantren bertujuan untuk mengarahkan pada Tafaqquh fi al Din. Dalam tradisi pesantren arti penting pengetahuan adalah untuk beribadah dan mengetahui bagaimana tata cara beribadah. Ibadah dalam pesantren menjadi dua macam: Pertama, melaksanakan doktrin agama atau perintah agama yang sudah jelas dan pasti. Ibadah dalam pengertian ini berorientasi pada kehidupan ukhrawi. Kedua, malaksanakan perbuatan-perbuatan yang benar, baik, dan bermanfaat bagi dirinya dan bagi kepentingan bersama; meliputi manfaat lahiriyah dan batiniyah. Perwujudan ibadah kedua ini sepenuhnya berada dalam kewenangan, pemikiran dan keinginan manusia untuk melaksanakanya yang berorientasi pada kehidupan duniawi. ${ }^{11}$

Islam mengajarkan bahwa kehidupan duniawi ini bagian dari kehidupan ukhrawi, dan bentuk kehidupan ini adalah satu kesatuan yang tidak dapat dipisahkan antara satu dengan yang lain. Kehidupan ukhrawi tergantung pada amalan-amalan manusia di dunia; dan kelurusan amalan manusia di dunia sangat tergantung pada keyakinanya terhadap kehidupan akhirat. Kedudukan dua ibadah ini tidak dapat saling

${ }^{8}$ Dhofier, Tradisi Pesantren, 44.

9 Imam Bawani, Tradisionalisme dalam Pendidikan Islam; Studi atas Daya Tahan Pesantren Tradisional (Surabaya: Penerbit Al-Ikhlas, 1993), 89.

${ }^{10}$ Mastuhu, Dinamika Sistem Pendidikan Pesantren, 6.

11 Mastuhu, 'Prinsip Pendidikan Pesantren', dalam Manfred Oepen dan Wolfgang Karcher (ed), Dinamika Pesantren; Kumpulan Makalah Seminar International "The Role Of pesantren In Education and Community Development in Indonesia" Berlin 9-13 juli 1987, Terj. Sonhaji Soleh (Jakarta: Penghimpunan Pengembangan Pesantren dan Masyarakat (P3M), 1988), 278. 
menggantikan kedudukan masing-masing. Keduanya merupakan bentuk instrumen ibadah yang sangat penting, dan saling melengkapi, dan samasama mempunyai peranan penting dalam membentuk karakter para santri. $^{12}$

Abdurrahman Wahid, memaparkan bahwa ada tiga instrumen khas dalam dunia pesantren dalam menata nilai pendidikanya, di antaranya: Pertama, kepemimpinan kiai, baik dengan kepemimpinan dengan masyarakat atau dengan kiai yang lain. Hal ini menunjukkan bagaimana kiai memelihara relasi kolegial. Dalam hal ini aspek yang sangat penting muncul, yaitu pemeliharaan tradisi Islam, yaitu kekuatan ulama sebagai pemangku keilmuan agama Islam yang kemudian akan diwariskan kepada santri-santrinya. Kepemimpinan kiai menyediakan kerangka bagi santri dalam menjalankan tugasnya untuk memelihara ilmu-ilmu agama. Kepemimpinan kiai tidak akan bias dilepaskan dengan konsep kharisma kiai, yang mempunyai pengaruh yang sangat besar terhadap kehidupan pesantren. ${ }^{13}$ Kedua, literatur universal yang dipelihara dan diwariskan dari generasi ke generasi yang secara langsung berkaitan dengan konsep yang unik tentang kepemimpinan kiai. Kitab kuning menciptakan kesinambungan 'tradisi yang benar' dalam memelihara ilmu-ilmu agama sesuai yang diwariskan dalam masyarakat Islam oleh para pendahulu. Ketiga, sistem nilai yang unik. Sistem nilai ini yang jelas tidak akan pernah lepas dari unsur sistem nilai yang lain yaitu kepemimpinan kiai dan literatur yang universal, pembakuan ajaran-ajaran Islam tentang kehidupan sehari-hari bagi kiai dan santri melegitimasikan kitab-kitab sebagai sumber tata nilai dan kiai sebagai model implementasinya dalam kehidupan sosial. ${ }^{14}$

Ketiga unsur utama pesantren tersebut saling berkaitan dan tidak dapat dipisahkan. Namun, berbagai tantangan dari luar pesantren menyebabkan pola masing-masing unsur itu terbuka untuk menerima perubahan tertentu. Misalnya sistem nilai pesantren tersebut harus

12 Ibid.

${ }^{13}$ Nama dan pengaruh pengaruh Pesantren berkaitan erat dengan kharisma kiai. Kuatnya kecakapan dan pancaran kepribadian kepemimpinanseorang pimpinan pesantren sangat menentukan tingkat dan kedudukan suatu pesantren. Lihat dalam M. Ridlwan Nasir, Mencari Tipologi Format Pendidikan Ideal; Pondok Pesantren Ditengah Arus Perubahan (Yogyakarta; Pustaka Pelajar, 2005), 13. Bandingkan dengan Abdullah, "Kurikulum Pesantren dalam Perspektif Gus Dur; Suatu Kajian Epistemologis", Jurnal Pendidikan Agama Islam (Journal of Islamic Education Studies), Vol. 4, No. 2 (2016).

${ }^{14}$ Lihat, Mohammad Muchlis Solichin, "Interrelation Kiai Authorities, Curriculum and Learning Culture in Pesantren Indonesia", Tarbiya: Journal of Education in Muslim Society, Vol. 5, No. 1 (June 2018). 
memasukkan ijazah tertulis yang dikeluarkan pemerintah. Kitab universal tersebut sekarang harus bersaing dengan materi-materi pembelajaran yang lebih baru dan sederhana yang disusun untuk sekolah-sekolah agama negeri yang berada di lingkungan pesantren. Di samping persaingan dalam literatur keagamaan, kepemimpinan kiai saat ini tunduk kepada rencana-rencana institusionaisasi yang diberikan, baik itu tuntutan dari luar maupun dalam pesantren. ${ }^{15}$

Dalam mengkaji sebuah pesantren, outsider mungkin melihat pesantren sebagai entitas yang homogenik. Namun apabila diteliti selanjutnya, kiai dan pesantren memiliki corak keagamaan yang tidak selalu sama, baik dari segi metodologi pembelajaran yang dikembangkan, madzhab keagamaan, serta sikap politik maupun manajerial lembaga. ${ }^{16}$ Dalam pandangan penulis, tidak dibenarkan membuat generalisasi karakter kiai dan pesantrennya. Realitasnya, saat ini bermunculan orang dengan panggilan kiai, namun tidak memiliki lembaga pendidikan Islam seperti pesantren.

\section{Dinamika Pengembangan Kurikulum Pesantren}

Dalam beberapa penelitian terkait pondok pesantren ditemukan bahwa pesantren mempunyai kewenangan tersendiri dalam menyusun dan mengembangan kurikulumnya. Secara umum kurikulum pesantren dapat dipetakan menjadi 4 (empat), di antaranya : pendidikan agama, pengalaman dan pendidikan moral, sekolah dan pendidikan umum serta ketrampilan dan kursus. ${ }^{17}$ Pertama, kurikulum berbentuk pendidikan agama Islam. Di dalam dunia pesantren, kegiatan belajar pendidikan agama Islam lazim disebut sebagai ngaji atau pengajian. Kegiatan ngaji di pesantren pada praktiknya dibedakan menjadi dua tingkatan. Pada tingkatan awal ngaji sangatlah sederhana, yaitu para santri belajar membaca teks-teks Arab, terutama sekali al-Qur'an. Tingkatan ini dianggap sebagai usaha minimal dari pendidikan agama yang harus dikuasai oleh para santri. Tingkatan berikutnya adalah para santri memilih kitab-kitab islam klasik dan mempelajarinya di bawah bimbingan kiai. Adapun kitab-kitab yang dijadikan bahan untuk ngaji meliputi bidang ilmu: fikih, aqidah atau tauhid, nahwu, sharaf, balaghah,

15 Ibid., 270-271.

${ }^{16}$ Komaruddin Hidayat, 'Kiai dan Dunia Pesantren', dalam, Marwan Sardijo (Peny), Mereka Berbicara Pendidikan Islam; Sebuah Bunga Rampai (Jakarta: Raja Grafindo Persada, 2009), 5.

${ }^{17}$ Abdullah Aly, Pendidikan Islam Mulltikulturalisme di Pesantren; Telaah Kurikulm Pondok Pesantren Islam Assalam Surakarta (Yogyakarta; Pustaka Pelajar, 2011), 184.

162 Jurnal El-Banat 
hadith, tasawuf, akhlak, ibadah-ibadah seperti sholat doa, dan wirid. Kedua, kurikulum berbentuk pengalaman dan pendidikan moral. Kegiatan keagamaan yang paling terkenal di dunia pesantren adalah kesalehan dan komitmen para santri terhadap lima rukun Islam. Kegiatankegiatan tersebut diharapkan mampu menumbuhkan kesadaran para santri untuk mengamalkan nilai-nilai moral yang di ajarkan pada saat ngaji. Ketiga, kurikulum berbentuk sekolah dan pendidikan umum. Pesantren memberlakukan kurikulum sekolah mengacu kepada pendidikan nasional yang dikeluarkan Departemen Pendidikan Nasional, sedangkan kurikulum Madrasah mengacu kepada pendidikan Agama yang diberlakukan oleh Departemen Agama. Keempat, kurikulum berbentuk ketrampilan dan kursus. Pesantren memberlakukan kurikulum yang berbentuk ketrampilan dan kursus secara terencana dan terpogram melalui kegiatan ekstrakulikuler. Adapun kursus yang popular di pesantren adalah bahasa Inggris, komputer, reparasi sepeda motor, dan lain sebagainya. ${ }^{18}$

Sedangkan M Ridlwan Nasir, memberikan deskripsi mengenai tingkat keanekaragaman pranata sesuai dengan spektrum komponen serta pengembangan suatu pesantren. Yang diklasifikasikan menjadi lima bagian, yaitu; Pertama, pondok pesantren salaf; yaitu pondok pesantren yang di dalamnya terdapat sistem pendidikan salaf (weton, sorogan, bandongan) dan sistem klasikal. Kedua, pondok pesantren semi berkembang; yaitu pondok pesantren yang didalamnya terdapat sistem pendidikan salaf (weton, sorogan, bandongan) dan sistem klasikal (madrasah) swasta dengan kurikulum 90\% agama dan 10\% umum. Ketiga, pondok pesantren berkembang; yaitu pondok pesantren seperti semi berkembang, hanya saja sudah lebih bervariasi dalam bidang kurikulumnya, yakni $70 \%$ agama dan $30 \%$ umum. Di samping itu, diselenggarakan pula madrasah SKB tiga menteri dengan penambahan diniyah. Keempat, pondok pesantren khalaf/modern; yaitu seperti pondok pesantren berkembang, hanya saja sudah lebih lengkap lembaga pendidikan yang ada di dalamya, antara lain diselenggarakan sistem sekolah umum dengan penambahan diniyah (praktek membaca kitab salaf), perguruan tinggi (baik umum, maupun agama), bentuk koperasi dan dilengkapi dengan takhassus (bahasa Arab dan bahasa Inggris). Kelima, pondok pesantren ideal. Pondok pesantren ini lebih lengkap, terutama bidang ketrampilan yang meliputi pertanian, teknik, perikanan, perbankankan, dan benar-benar memperhatikan kualitasnya dengan tidak

${ }^{18}$ Ahmad Saifuddin, "Eksistensi Kurikulum Pesantren Dan Kebijakan Pendidikan", Jurnal Pendidikan Agama Islam (Journal of Islamic Education Studies), Vol. 3, No. 1 (2015). 
mengubah karakter pesantren yang masih relevan dengan kebutuhan masyarakat. ${ }^{19}$

Dalam dinamikanya, pesantren tidak semata-mata tumbuh atas pola lama yang bersifat tradisional dengan hanya menggunakan pola sorogan dan bandongan. Dalam perkembanganya ada tiga sistem pembelajaran yang dikembangkan di pesantren, yaitu ${ }^{20}$ Pertama, sistem klasikal. Pola penerapan sistem klassikal adalah dengan pembentukan kelas-kelas dan tingkatan, kluster pembelajaran yang disesuaikan seperti pada sekolah dalam pendidikan formal. Dalam banyak pesantren pola ini sudah banyak di gunakan di sebagai madrasah diniyah atau kegiatan dalam pesantren sebagai pengelompokan pembelajaran yang didasarkan atas kemampuan dan pemahaman selama di pesantren tersebut. Kedua, sistem kursus. Pengajaran sistem kursus ini mengarah kepada terbentuknya santri-santri yang mandiri dalam menopang ilmu-ilmu agama yang mereka terima dari Kiai melalui pengajaran sorogan dan bandongan. Sebab pada umumnya para santri diharapkan tidak tergantung kepada pekerjaan di masa mendatang, melainkan harus mampu menciptakan pekerjaan sesuai dengan kemampuan mereka. ${ }^{21}$ Ketiga, sistem pelatihan. Pola pelatihan ini dikembangkan untuk menumbuh kembangkan kemampuan praktis seperti pelatihan, pertukangan, perkebunan, perikanan, manajemen koperasi dan kerajinan-kerajinan yang mendukung tercinptanya kemandirian integratif. ${ }^{22}$ Dalam banyak pesantren telah banyak diusahakan dan di didik pengalaman dan pembelajaranya secara intensif agar para santrinya mempunyai kemampuan kewirausahaan.

Sebagai respon terhadap pembaharuan pendidikan Islam, kebanyakan pesantren memasukkan ke dalam sistem pendidikanya dua model madrasah sekaligus: madrasah diniyah yang khusus mengajarkan ilmu-ilmu agama dan madrasah-umum yang inklusif untuk ilmu-ilmu non-keagamaan. ${ }^{23}$ Madrasah umum inilah yang kemudian banyak berkembang dan diklasifikasikan kembali penjenjanganya menjadi madrasah Ibtidaiyah, Tsanawiyah, dan Aliyah. Pertumbuhan yang signifikan terhadap perkembangan madrasah di Indonesia, pemerintah melakukan pengembangan dalam sistem pendidikan keagamaanya dengan cara pembinaan dan pengembangan madrasah yang sebagian besar bertumpu pada madrasah-madrsah yang telah berdiri. Pendirian

\footnotetext{
${ }^{19}$ M. Ridlwan Nasir, Mencari Tipologi Format Pendidikan Ideal; Pondok Pesantren di Tengah Arus Perubahan (Yogyakarta: Pustaka Pelajar, 2005), 87-88.

${ }^{20}$ Binti Ma'unah, Tradisi Intelektual Santri (Yogyakarta: TERAS, 2009), 185.

${ }^{21}$ Bahri Ghazali, Pesantren Berwawasan Lingkungan (Jakarta: Prasasti, 2002), 32.

${ }^{22}$ Ma'unah, Tradisi Intelektual Santri, 186.

${ }^{23}$ Ibid., 110.
} 
madrasah-madrasah negeri pun mulanya juga berasal dari madrasah yang telah dikembangkan oleh pesantren.

\section{Kurikulum Pesantren Rifaiyah dan Pendidikan Nasional; Posisi dan Dialektika}

Penggantian kurikulum pendidikan nasional sudah dilakukan lebih dari lima kali dalam 30 tahun terkakhir, dan kalau dihitung penggantian kurikulum sejak sistem pendidikan nasional dirumuskan pasca kemerdekan, kita mencatat 10 kali terjadi penggantian kurikulum. yaitu pada tahun 1947, 1952, 1964, 1968, 1975, 1984, 1994, 2004, 2006 dan 2013. Tetapi dalam hal ini, Abd Rachman Assegaf mengklasifikasikan pengembangan kurikulum menjadi kedalam tiga tahapan. Yaitu; sebelum rencana pendidikan 1964, rencana pendidikan 1964, dan kurikulum 1968 sampai sekarang. ${ }^{24}$ Dalam hubunganya terhadap pengembangan kurikulum pendidikan di pesantren dan madrasah, madrasah mulai diperhatikan dan menjadi bagian dari kebijakan sistem pendidikan nasional adalah ketika penggodokan kurikulum 1973. Secara berurutan bagaimana hubungan kurikulum pendidikan nasional, kemudian memberikan dampak bagi pengembangan kurikulum pondok pesantren Rifaiyah dijelaskan sebagai berikut:

1. Kurikulum Pra-1973

Pesantren, madrasah dan berbagai lembaga pendidikan Islam sebelum kemerdekaan adalah lembaga pendidikan yang murni dikelola secara swadaya oleh masyarakat, jadi setelah kemerdekaan lembaga pendidikan Islam tersebut tidak mempunya masalah secara eksistensial. Keberadaanya di Indonesia sudah berlangsung sangat panjang dan memasyarakat. Untuk kepentingan ini, pada tahun 1946 dibentuklah, Departemen Agama yang antara lain mengurusi pengajaran agama di sekolah negeri dan swasta, pengajaran umum di madrasah, dan penyelenggaraan Pendidikan Guru Agama (PGA) dan Pendidikan Hakim Islam Negeri. Penyelenggaran pendidikan pada masa ini dibuat melalui rencana pelajaran (kurikulum) 1947 yang baru dilaksanakan di sekolah-sekolah pada tahun 1950. Benntuknya memuat dua hal pokok, yaitu daftar mata pelajaran, dan garis-garis besar pengajaran (GBPP). ${ }^{25}$

24 Abd Rachman Assegaf, Politik Pendidikan Nasional; Pergeseran Pendidikan Agama Islam dari Proklamasi ke Reformasi (Yogyakarta; Karunia Kalam, 2005), 135.

25 Oemar Hamalik, Dasar-Dasar Pengembangan Kurikulum (Bandung; Rosda, 2008), 12. 
Setelah renjtana pelajaran (kurikulum 1947), kemudian disempurnakan dengan rentjana pelajaran terurai (kurikulum 1952). Kurikulum ini mengarah kepada sistem pendidikan nasional. Pengembangan kurikulum ini sangat dipengaruhi oleh kebijakan presiden Soekarno, dan kebijakan untuk memerhatikan pendidikan Agama baru di upayakan, meskipun belum menemukan keberhasilan yang signifikan. Dalam konteks pesantren Rifaiyah, pada periode ini masih berupa pesantren salaf, dan belum memiliki lembaga pendidikan formal. Perubahan kebijakan kurikulum nasional tidak banyak berpengaruh, disamping pada saat ini pendidikan Islam belum begitu diperhatikan dan dimasukkan dalam sistem pendidikan nasional.

Pengembangan kurikulum pesantren terletak pada pembangunan metode yang relevan terhadap perkembangan zaman, dan mengupayakan beberapa santri untuk melihat sekolah formal yang diselenggarakan pemerintah, untuk melihat bagaimana yang terjadi dengan pendidikan umum yang diselenggarakan pemerintah. Penguatan kurikulum pesantren terletak pada bagaimana santri dapat mengamalkan ilmunya dengan baik, dan bagaimana agar mereka mampu bertahan dengan pendanaan dan fasilitas yang seadanya. Pola pendidikan yang konvensional masih mendominasi dan pembaruan pendidikan Islam belum merambah sampai ke pelosok-pelosok desa, seperti halnya lingkungan tempat pesantren Rifaiyah tumbuh dan berkembang.

2. Kurikulum 1973

Periode ini adalah di mana pesantren dan madrasah mulai mendapatkan posisi dalam kebijakan yang dibuat pemerintah, melalui kebijakan dengan mengembangkan kurikulum madrasah pada 1973, maka infrastruktur dan pengembangan kelembagaan secara konkrit di wujudkan dalam menata kelembagaan madrasah di Indonesia. Politik orde baru yang lebih memerhatikan pendidikan Islam mulai membangun dan mengembangkan kelembagaan madrasah. Produk kebijakkan pemerintah orde baru tertuang dalam Tap MPRS No. VII/MPRS/1966, dengan mengupayakan pembenahan dan pembangunan instrument pembelajaran. ${ }^{26}$ Kebijakan Depertemen Agama melalui dukungan peemrintah untuk menegerikan madrasahmadrasah di mulai pada tahun 1976, sejauh usaha ini 123 Madrasah

\footnotetext{
${ }^{26}$ Maksum, Madrasah Sejarah dan Perkembanganya (Jakarta: Logos Wacana Ilmu,
} 1999), 141. 
Ibtidaiyah dinegerikan menjadi total 258 MIN. dalam waktu yang bersamaan juga berdiri $182 \mathrm{MTsN}$ dan $42 \mathrm{MAN}$.

Pelengkapan struktur madrasah dari madrasah Ibtidaiyah sampai Aliyah pada tahun 1970, dengan melakukan perumusan kurikulum madrasah dalam semua tingkatan dalam skala nasional. Rumusan tersebut kemudian diberlakukan melalui keputusan Menteri Agama No.52 Tahun 1971, yang kemudian dikenal dengan kurikulum 1973. Pada kurikulum 1973 inilah standarisasi kurikulum madrasah dalam skala nasional mulai diberlakukan dalam setiap jenjang, dengan penataan yang terstruktur mulai madrasah Ibtidaiyah, Tsanawiyah, sampai kepada Madrasah Aliyah.

Peningkatan mutu dan pembinaan yang dilakukan terhadap madrasah dilakukan secara terus menerus, dan dengan dikeluarkanya Kepres No. 34 Tahun 1972 dan Inpres No. 15 Tahun 1974, pemerintah mengambil kebijakan yang lebih operasional dalam kaitanya terhadap madrasah. Pada tahun 1975 dikeluarkan Surat Keputusan Bersama (SKB) Tiga Menteri mengenai "peningkatan mutu pendidikan madrasah". Dalam keputusan tersebut, masing-masing Kementerian Agama, Kementerian Pendidikan dan Kebudayaan, dan Kementerian Dalam Negeri memiliki tanggung jawab dalam pembinaan dan pengembangan pembinaan madrasah. ${ }^{27}$

Posisi pesantren Rifaiyah Pati yang masih dalam tahap pembangunan fisik dan kelembagaan belum mempunyai lembaga pendidikan formal yang Nampak pada periode ini, oleh karena penelitian ini juga mengambil setting tahun 1974, dan pada saat itu pesantren Rifaiyah masih dalam taraf mengembangkan pendidikan pesantren saja belum pada taraf mengembangan madrasah dan lembaga pendidikan formal lain. Hal ini dapt dimaklumi Karena pesantren Rifaiyah jauh dari pusat ibu kota, dan organisasi Rifaiyah dalam sekala nasional belum terbentuk. ${ }^{28}$

Pembangunan kelembagaan masih berupa penyempurnaan fisik, pembuatan bangunan bilik-bilik pondok pesantren, dan pembangunan masjid sebagai pusat ibadah dan berbagai kegiatan pengajian. Mengingat pendanaan pesantren dilakukan scara swadaya, dan saat itu bantuan pemerintah untuk pembangunan pesantren masih sangat minim, untuk melakukan pembangunan fisik saja dibutuhkan waktu

${ }^{27}$ Ibid., 149.

28 Organisasi Rifaiyah secara nasional baru dibentuk pada tahun 1984, fase-fase sebelum itu beberapa pesantren Rifaiyah hanya mempunyai ikatan kultural, dan belum ada tata cara dan struktur yang mengikat antar pesantren Rifaiyah di beberapa daerah. 
yang bertahun-tahun karena minimnya pendanaan, dan berbagai bentuan seadanya dari masyarakat sekitar.

3. Kurikulum CBSA (Cara Belajar Siswa Aktif)

Kurikulum 1984 yang lebih dikenal sebagai kurikulum CBSA dengan mengusung "process skill active", proses menjadi lebih penting dalam pelaksanaan pendidikan. Mempunyai dasar dan tujuan yang sama dengan kurikulum 1975, dengan mengedepankan keaktifan siswa dalam pembelajaran, siswa diperankan membentuk suatu pengetahuan dengan diberikan kesempatan untuk megemukakan pendapat, bertanya dan mendiskusikan sesuatu. ${ }^{29}$

Dalam kurikulum ini pengembangan madrsah masih melanjutkan upaya pengembangan kelembagaan setelah dikeluarkanya SKB tiga menteri, pengembangan kurikulum dilakukan oleh pusat dan kemudian disosialisasikan dan melakukan berbagai evaluasi terkait bagaimana imlementasinya di daerah dan madrasah-madrasah yang dikelola oleh yayasan swasta dan pesantren yang dimiliki oleh kiaikiai di desa-desa.

Program pemerataan pendidikan di daerah juga mulai menyentuh pada pesantren Rifaiyah. Pada tahun 1982 untuk pertama kalinya Pesantren Rifaiyah membangun madrasah Ibtidaiyah, dan dilanjutkan pada tahun 1988 untuk mulai membangun madrasah Tsanawiyah. Periode ini adalah periode di mana pesantren Rifaiyah mulai secara serius menata program pendidikan formalnya dengan berbagai bantuan dan kerja sama dengan pemerintah, terkait pengembangan kurikulum pendidikan di madrasah. ${ }^{30}$

4. Kurikulum 1994 dan Suplemen Kurikulum 1999

Ditetapkannya UU No.2/ 1989 tentang Sistem Pendidikan Nasional dianggap sebagai penopang lahirnya kurikulum 1994. Pada kurikulum 1994 pendidikan dasar harus selesai menjadi sembilan tahun (setingkat SD dan SMP). Kurikulum 1994 berupaya meyatukan kurikulum sebelumnya, yaitu kurikulum 1975 dengan pendekatan tujuan dan kurikulum 1984 dengan pendekatan proses. Hal ini berimplikasi lebih jauh terhadap penndidikan nasional mencakup jalur sekolah dan luar sekolah, serta jenis-jenis pendidikan akademik,

${ }^{29}$ Hamalik, Dasar-dasar Pengembangan Kurikulum, 86.

30 Pesantren Rifaiyah Miftahul Muhtadin Pati, adalah pesantren Rifaiyah yang pertama kali membenntuk lembaga pendidikan formal, yaitu madrasah dan sekolah. Dan sampai sekrang ini belum ada peraturan terperinci oleh Pimpinan Pusat Rifaiyah mengenai pengembangan lembaga pendidikan formal di pesantren Rifaiyah. 
pendidikan professional, pendidikan kejuruan dan pendidikan keagamaan. ${ }^{31}$

Dengan adanya keputusan Menteri Agama RI NO. 372/ 1993 tentang Kurikulum Pendidikan Dasar Berciri Khas Agama Islam. Dalam keputusan ini diatur bahwa Madrasah Ibtidaiyah dan Madrasah Tsanawiyah melaksanakan Kurikulum Sekolah Dasar dan Sekolah Lanjutan Tingkat Pertama. ${ }^{32}$ Karena menurut UUSPN tahun 1989 sekolah Islam harus mengikuti sistem sekolah negeri, maka sekolah Islam mengambil sepenuhnya kurikulum yang disusun dan dikeluarkan Departemen Pendidikan dan Kebudayaan. Akhirnya tidak ada perbedaan antara sekolah islam dan sekolah umum (negeri). Yang membedakan hanyalah penekanan khusus pada pelajaran agama; sekolah Islam mempunyai banyak mata pelajaran yang berhubungan dengan Islam dan sebagai akibatnya, memiliki jam belajar yang lebih lama untuk pelajaran tersebut. ${ }^{33}$

Sejalan dengan undang-undang pendidikan 1989, madrasah juga harus menerapkan kurikulum nasional 1994. Oleh sebab itu, madrasah pada dasarnya sepadan dengan sekolah umum, hanya sedikit sekali perbedaan di antara keduanya. Keberadaan madrasah dalam hal ini dapat dijelaskan dalam dua hal, yaitu; (1) ia telah memiliki kedudukan yang sama dengan sekolah-sekolah umum lainya. Implikasi dari hal ini adalah ia harus mengajarkan materi-materi pelajaran yang sama sebagaimana diajarkan sekolah sekolah umum lainya, terutama bidang eksakta (matematika, fisika, kimia, dan biologi). (2) meskipun madrasah (menurut kurikulum 1994) telah dikonversi menjadi sekolah umum berciri khas agama Islam, namun identitas tersebut belum mendapatkan rumusanya secara spesifik dan distingtif. (3) kurikulum madrasah yang membengkak karena harus menggunakan kurikulum Depdikbud dan Depag secara bersamaan. Hal ini merupakan persoalan yang serius, karena harus

31 Undang-Undang Sistem Pendidikan Nasional (Jakarta; Golden Terayon Press, 1994). Lihat juga dalam Maksum, Madrasah Sejarah dan Perkembanganya, 155.

${ }^{32}$ Kedudukan keduanya (MI dan MTs) sebagai sekolah berciri khas Islam masingmasing berdasarkan KMA No. 368/93 dan 3969/93 tanggal 22 Desember 1993, dengan menindaklanjuti SK Mendikbud No.0487/U/1992 dan No. 054/U/1993. Lihat, Kantor Wilayah Departemen Agama Jawa Barat, Himpunan Peraturan Perundang-undangan Bidang Pendidikan Keagamaan (Bandung Departemen Agama, 1994), 335.

${ }^{33}$ Azra, Pendidikan Islam, 71. 
mempertimbangkan kemampuan siswa untuk menyerap semua pelajaran yang sangat banyak tersebut. ${ }^{34}$

Posisi pesantren Rifaiyah sama peliknya ketika menyelenggaraka penndidikan untuk madrasah Ibtidaiyah dan madrasah Tsanawiyah Miftahul Muhtadin, disi lain kebutuhan untuk menyelenggarakan pendidikan formal merupakan kebutuhan nyata, tetapi pendidikan formal melalui madrasah tersebut sangat nyata mereduksi jam belajar untuk memahami pelajaran Agama, pada akhirnya belajara di pesantren pun akan di kalahkan karena kesibukan siswa dan santri belajar di sekolah formal madrasah karena banyaknya mata pellajaran yang harus dikuasai.

Sampai pada tahun 2004 para santri pesantren Rifaiyah diberikan pilihan untuk ikut dalam pendidikan formal madrasah atau hanya mengikuti madrasah diniyah dan kegiatan pengajian. Akan tetapi, seiring berjalanya waktu dan kebutuhan akan memiliki ijazah pendidikan formal, maka lambat laun santri yang hanya mengikuti pendidikan di madrasah diniyah dan kegiatan pondok pesantren mengalami penurunan dari segi kuantitas, sehingga pada akhirnya kebanyakan santri di pesantren Rifaiyah kesemuanya juga bersekolah di madrasah miftahul muhtadin sebagai madrasah binaan pesantren Rifaiyah Pati.

5. Kurikulum Berbasis Kompetensi

Kurikulum tahun 2004 adalah respon dari tuntutan reformasi, di antaranya UU No. 2 Tahun 1999 tentang pemerintah daerah, UU No. 25 Tahun 2000 tentang kewenangan pemerintah dan kewenangan propinsi sebagai daerah otonom dan tap MPR No. IV/MPR/1999 tentang arah kebijakan pendidikan nasional. $\mathrm{KBK}$ tidak lagi mempersoalkan proses belajar. Proses belajar mengajar merupakan otoritas wilayah guru, yang terpenting pada tingkatan tertentu, peserta didik mencapai kompetensi yang diharapkan. Kompetensi dimaknai sebagai keterpaduan pengetahuan, ketrampilan, nilai, sikap yang telah direfleksikan dalam kebiasaan berfikir dan bertindak. ${ }^{35}$

Penerapan kurukulum KBK di beberapa madrasah dan sekolah umum yang dibina oleh pesantren belum menemukan hasil yang baik, permasalahan waktu yang sangat sempit (2 tahun yang kemudian diganti oleh KTSP), untuk madrasah mengimplementasikan sangatlah sulit, apalagi memberikan dampak terhadap kegiatan belajar mengajar.

\footnotetext{
${ }^{34}$ Lihat, Azyumardi Azra, Paradigma Baru Pendidikan Nasional: Rekonstruksi dan Demokratisasi (Jakarta: Kompas Gramedia,2002), 80.

35 Lihat dalam E Mulyasa, Kurikulum Berbasis Kompetensi (Bandung: Remaja Rosda Karya, 2003), 42.
} 
Bagaimana posisi pesantren dalam melihat perkembangan kurikulum ini, karena sifatnya hanya sebagai landasan operasional untuk sistem pengajaran, beberapa lembaga pendidikan Islam tidak banyak mengalami perubahan dalam proses pengajaranya, termasuk dalam hal ini pesantren Rifaiyah.

Pada periode ini pesantren Rifaiyah menyelenggarakan pendidikan menengah yaitu SMA Rifaiyah, yang mengadopsi kurikulum Depertemen Pendidikan Nasional. Karena terkait perizinan dan jumlah kuantitas Madrasah Aliyah di wilayah kabupaten Pati, pesantren Rifaiyah menyelenggarakan pendidikan SMA bukan MA, penerapaa kurikulum 2004 dan sebagian besar masih menggunakan pola kurikulum 1994, tidaklah digunakan secara baku, hal itu dapat dilihat dari muatan kurikulum agama islam dan kurikulum kepesantrenan dan kitab kuning mempunyai porsi yang cukup banyak dalam distribusi mata pelajaran kurikulum SMA Rifaiyah.

Untuk kurikulum Madrasah Ibtidaiyah dan Madrasah Tsnawiyah Miftahul Muhtadin, masih menggunakan kurikulum 1994, yang kemudian dalam transisi kurikulum 2004, mengingat keberadaan akses informasi di daerah tidaklah sekuat di perkotaan, maka implementasi kurikulum baru tidaklah dapat dengan cepat dapat di implementasikan. Tetapi bagaimanapun perubahan bentuk kurikulum pendidikan nasional, pesantren Rifaiyah dalam penyelenggaraan pendidikan formal mempunyai acuan tersendiri dalam memasukkan kurikulum pelajaran kitab tarjumahnya dan kemudian member bekal pemahaman agama melalui pengajaran kitab kuning, yang diberikan dalam muatan pelajaran di pendidikan formal.

6. Kurikulum Tingkat Satuan Pendidikan

KTSP merupakan penyempurna dan penegas implementasi KBK. KTSP lahir sebagai respon dari UU No. 20 tahun 2003 tentang Sistem Pendidikan Nasional, terutama pasal 36 ayat 1 dan 2 dan peraturan pemerintah RI No. 19 Tahun 2005 tentang Standar Nasional Pendidikan. $^{36}$ Kurikulum ini bertujuan memandirikan dan memberdayakan satuan pendidikan melalui pemberian kewenangan kepada lembaga pendidikan. Penyusunan KTSP oleh sekolah dimulai pada tahun ajaran 2006/2007 dengan mengacu kepada Standar Isi (SI) dan Standar Kompetensi Lulusan (SKL) untuk pendidikan dasar dan menengah sebagaimana diterbitkan melalui Peratutan Menteri

${ }^{36}$ E. Mulyasa, Implementasi Kurikulum Tingkat Satuan Pendidikan (Jakarta: Bumi Aksara, 2010), 25. 
Pendidikan Nasional No. 22 dan No. 23Tahun 2006, serta panduan pengembangan KTSP yang telah dikeluarkan oleh BSNP. ${ }^{37}$

Kurikulum KTSP yang mempunyai jarak hanya 2 tahun setelah penerappan kurikulum KBK, dalam pespektif pendidikan daerah terlihat begitu membingungkan, oleh karena itu respon yang terjadi oleh pendidikan formal berbasis pesantren (pesantren Rifaiyah) adalah kelihatan seperti mengikuti dengan tidak sungguh-sungguh, maksudnya adalah perubahan kurikulum seperti itu hanyalah merupakan formalitas dan alat kelengkapan kurikulum lembaga pendidikan yang mengikuti program kurikulum pemerintah. Pendidikan formal di pesantren Rifaiyah mempunyai kurikulum tersendiri dalam mengajarkan pendidikan keagamaanya melalui kajian kitab tarjumah, dan pengajian kitab kuning. Untuk kurikulum mata pelajaran umum pesantren Rifaiyah sepenuhnya mengikut kurikulum pemerintah, tetapi untuk kurikulum keagamaan selain mengikuti kurikulum yang di edarkan oleh departemen agama, pesantren rifaiyah juga mempunyai acuan kurikulum sendiri yang digagas dan dirumuskan oleh para pimpinan pesantren Rifaiyah.

Posisi pesantren Rifaiyah dalam menyerap kurikulum nasional, tidaklah begitu signifikan. Mengingat terkait pendidikan umum pesantren Rifaiyah tidaklah mempunyai landasan tersendiri, tetapi mengikut bagaimana keputusan pengembangan kurikulum yang dilakukan oleh pemerintah. Lain halnya dengan kurikulum pendidikan keagamaan, selain mengikuti program pemerintah melalui Departemen Agama, pesantren Rifaiyah juga mempunyai acuan pengembangan kurikulum tersendiri, yang di dasarkan atas pemahaman mereka atas ajaran KH Ahmad Rifai Kalisalak.

7. Kurikulum 2013

Kurikulum 2013 sebagai pengembangan demi kemudahan pelaksanaan KTSP, lebih mengedepankan kreatifitas guru dalam memprogram pengajaran, sayangnya kurikulum 2013 sampai saat ini terbatas dilaksanakan di beberapa sekolah, artinya tidak semua sekolah di Indonesia sudah menerapkan kurikulum 2013, termmasuk dalam hal ini madrasah baik itu madrasah negeri maupun madrasah swasta. Oleh karena kurikulum ini adalah kurikulum baru dan bahkan belum mampu diimplementasikan di sekolah formal dalam lingkungan pesantren Rifaiyah (MI, MTs Miftahul-Muhtadin dan SMA Rifaiyah Pati ), maka dalam hal penelitian ini juga belum mampu melihat bagaimana respon lembaga pendidikan formal pesantren Rifaiyah

${ }^{37}$ Ibid., 25-26. 
dalam merespon pengembangan kurikulum tersebut terkait posisi dan dinamisasi dalam pengembangan kurikulum pendidikanya.

Realitas lembaga pendidikan formal dibeberapa daerah (termasuk dalam hal ini pesantren Rifaiyah) menganggap kurikulum 2013 merupakan hal yang baru dan asing bagi keseharian mereka yang tidak terbiasa dengan arus perubahan, dan cepatnya pergeseran arus informasi. Latar belakang ini membuat respon pemangku kebijakan dalam pengembangan kurikulum pesantren Rifaiyah, terkesan lamban dan tidak proaktif dalam merespon perubahan kurikulumnasional yang baru, dengan menentukan posisi dan dinamisasi pengembangan kurikulum pesantren Rifaiyah atas pengembangan kurikulum pendidikan nasional yang digagasa oleh pemerintah. Core dalam pengembangan kurikulumnya tetap sama yaitu mencoba mengamalkan ajaran KH Ahmad Rifai Kalisalak, dengan mencoba mengakomodasi unsur-unsur baru yang dianggap positif dan mampu menunjang pemahaman ajaran agama Islam melalui pemikiran dan ajaran KH Ahmad Rifai Kalisalak dalam setiap lembaga pendidikan yang dijalankan pesantren Rifaiyah Pati ini.

Dalam konteks dan relevansinya terhadap pengembangan kurikulum pesantren Rifaiyah, penelitian dimulai dalam kurun 1974, pesantren Rifaiyah tetap mengikuti kurikulum pendidikan nasional apa adanya, dengan menyematkan kegiatan kurikulum kepesantrenan sebagai muatan lokal dan sebagai hidden kurikulum yang tidak disampaikan secara tertulis dalam laporan pembelajaran, tetapi melalui kultur yang dibangun dan proyek intelektual yang dibangun melalui tradisi dan budaya intelektual pesantren Rifaiyah.

Perubahan sistem pendidikan tampaknya tidak banyak berpengaruh terhadap perubahan kurikulum pesantren Rifaiyah. Perubahan dan pengembangan kurikulum pesantren Rifaiyah lebih banyak disebabkan oleh faktor kepemimpinan. Kiai atau ustadz yang berkepentingan mempunyai kemungkinan untuk menentukan arah, dan membuat kebijakan baru mengenai arah pengembangan kurikulum pendidikan yang dibuatnya. Hal itu biasanya disebabkan oleh faktor visi dan latar belakang pendidikan kiai dan ustadz tersebut, tidak sedikit ustadz sebagai salah satu keluarga kiai melakukan pembaruan terhadap pesantren keluarganya atau pesantren dari mana ia berasal, apakah ustadz yang membawa perubahan tersebut berasal dari pendidikan PTAIN, pendidikan timur tengah atau bahkan mereka yang sampai menempuh pendidikanya di negara-negara barat, sudah barang tentu mereka membawa bentuk perubahan yang bermacam-macam. Di antara mereka berbagai bentuk perubahan itu sudah pasti mengandung friksi, membawa konflik antar 
kiai, dan membuat sebuah dinamika sebuah perkembangan lembaga pendidikan, terutama di bidang kurikulum dan pembelajaranya.

\section{Kesimpulan}

Kesimpulan dari artikel ini adalah bahwa pondok pesantren Rifaiyah mempunyai perjalanan yang hampir sama dengan pesantren tradisional pada umunya saat ini, yaitu mengalami perkembangan dari pesantren tradisional yang hanya mengajarkan ilmu agama, membentuk pendidikan sekolah formal, membentuk kelembagaan yayasan pesantren dan membuat lembaga-lembaga penunjuang pendidikan. Secara spesifik beberapa perkembangan pesantren Rifaiyah mempunyai beberapa kasus yang unik dan dinamis, mulai pergeseran arah orientasi dan ideologi dalam pengembangan kurikulum dan tradisi intelektual dalam pendidikan, hingga pada pertentangan yang disebabkan oleh ketidak sepemahaman mengenai arah ideologis pesantren. Kasus-kasus spesifik ini tentu saja berpengaruh terhadap kebijakan kelembagaan yang dijalankan oleh pesantren Rifaiyah dalam penataan visi misi dan tujuanya ke depan. Beberapa hal yang melatarbelakangi perkembangan kurikulum pondok pesantren Rifaiyah, lebih tepatnya dilihat dari beberapa yang menjadikan adanya perubahan dan modernisasi dalam lembaga pendidikan. Dari hal ini penulis memberi benang merah bahwa perubahan pendidikan dan lembaga pendidikan selalu dimulai dari kurikulum pengajaran, kemudian merambah ke aspek yang lain seperti kelembagaan. Karena perubahan selalu muncul dari adanya wacana dan tuntuan perkembangan zaman yang kemudian akan diimplementasikan ke dalam kebijakan materi dan muatan pelajaran.

\section{Daftar Rujukan}

Abdullah. "Kurikulum Pesantren dalam Perspektif Gus Dur; Suatu Kajian Epistemologis". Jurnal Pendidikan Agama Islam (Journal of Islamic Education Studies), Vol. 4, No. 2 (2016).

Aly, Abdullah. Pendidikan Islam Mulltikulturalisme di Pesantren; Telaah Kurikulm Pondok Pesantren Islam Assalam Surakarta. Yogyakarta; Pustaka Pelajar, 2011.

AR, Zaini Tamin. "Dinamika Perkembangan Kurikulum Pendidikan Pesantren; Satu Analisis Filosofis". El-Banat: Jurnal Pemikiran dan Pendidikan Islam, Vol. 8, No. 1 (Juni 2018). 
Assegaf, Abd Rachman. Politik Pendidikan Nasional; Pergeseran Pendidikan Agama Islam dari Proklamasi ke Reformasi. Yogyakarta; Karunia Kalam, 2005.

Azra, Azyumardi. Paradigma Baru Pendidikan Nasional: Rekonstruksi dan Demokratisasi. Jakarta: Kompas Gramedia, 2002. . Pendidikan Islam; Tradisi dan Modernisasi di Tengah Tantangan Millenium III. Jakarta: Kencana Prenada Media Grup dan UIN Jakarta Press.

Bawani, Imam. Tradisionalisme dalam Pendidikan Islam; Studi Atas Daya Tahan Pesantren Tradisional. Surabaya: Penerbit AlIkhlas, 1993.

Bruinessen, Martin Van. Kitab Kuning, Pesantren dan Tarekat : Tradisi-Tradisi Islam di Indonesia. Bandung: Mizan, 1999, cet. Ke III.

Dhofier, Zamakhsari. Tradisi Pesantren; Studi tentang Pandangan Hidup Kyai dan Visinya Mengenai Masa Depan Indonesia. Jakarta; LP3ES, 2011.

Ghazali, Bahri. Pesantren Berwawasan Lingkungan. Jakarta: Prasasti, 2002.

Hamalik, Oemar. Dasar-Dasar Pengembangan Kurikulum. Bandung; Rosda, 2008.

Hidayat, Komaruddin. 'Kyai dan Dunia Pesantren', dalam, Marwan Sardijo (Peny), Mereka Berbicara Pendidikan Islam; Sebuah Bunga Rampai. Jakarta: Raja Grafindo Persada, 2009.

Kantor Wilayah Departemen Agama Jawa Barat, Himpunan Peraturan Perundang-undangan Bidang Pendidikan Keagamaan. Bandung Departemen Agama, 1994.

Ma'unah, Binti. Tradisi Intelektual Santri. Yogyakarta: TERAS, 2009.

Maksum. Madrasah Sejarah dan Perkembanganya. Jakarta: Logos Wacana Ilmu, 1999.

Mastuhu. 'Prinsip Pendidikan Pesantren', dalam Manfred Oepen dan Wolfgang Karcher (ed), Dinamika Pesantren; Kumpulan Makalah Seminar International "The Role Of pesantren In Education and Community Development in Indonesia" Berlin 9-13 juli 1987, Terj. Sonhaji Soleh. Jakarta: Penghimpunan Pengembangan Pesantren dan Masyarakat (P3M), 1988. 
. Dinamika Sistem Pendidikan Pesantren. Jakarta: INIS, 1994.

Mulyasa, E. Implementasi Kurikulum Tingkat Satuan Pendidikan. Jakarta: Bumi Aksara, 2010.

. Kurikulum Berbasis Kompetensi. Bandung: Remaja Rosda Karya, 2003.

Nasir, M. Ridlwan. Mencari Tipologi Format Pendidikan Ideal; Pondok Pesantren Ditengah Arus Perubahan. Yogyakarta; Pustaka Pelajar, 2005.

Rasyid, Ramli. "The Integration of the National Curriculum into Pesantren Education System". JICSA, Vol. 1, No. 2 (December 2012).

Saifuddin, Ahmad. "Eksistensi Kurikulum Pesantren dan Kebijakan Pendidikan". Jurnal Pendidikan Agama Islam (Journal of Islamic Education Studies), Vol. 3, No. 1 (2015).

Solichin, Mohammad Muchlis. "Interrelation Kiai Authorities, Curriculum and Learning Culture in Pesantren Indonesia". Tarbiya: Journal of Education in Muslim Society, Vol. 5, No. 1 (June 2018).

Undang-Undang Sistem Pendidikan Nasional. Jakarta; Golden Terayon Press, 1994. 